\title{
Aplikasi WebGis Fasilitas Umum Menggunakan Library Leaflet dan OpenStreetMap
}

\author{
$\mathrm{Ali}^{\mathrm{a} 1}$, M.Azhar Irwansyah ${ }^{\mathrm{b} 2}$, Haried Novriando ${ }^{\mathrm{b} 3}$ \\ a Program Studi Informatika Fakultas Teknik Universitas Tanjungpura \\ Jl. Prof. Dr. H. Hadari Nawawi, Kota Pontianak, 78115 \\ ${ }^{1}$ aliholdi94estudent.untan.ac.id \\ 2irwansyah.azharegmail.com \\ ${ }^{3}$ hariedeinformatika.untan.ac.id
}

\begin{abstract}
Abstrak
Keberadaan fasilitas-fasilitas umum di Kota Pontianak tersebar cukup merata di berbagai tempat, namun sampai saat tidak semua fasilitas umum diketahui oleh masyarakat lokal maupun mendatang. Oleh sebab itu diperlukan suatu sistem informasi yang dapat menyajikan informasi tentang lokasi fasilitas umun di Kota Pontianak. Tujuan penelitian ini untuk membangun aplikasi web gis untuk penyebaran fasilitas umum di Kota Pontianak. Metode yang digunakan dalam membuat sistem ini menggunakan metode waterfall. Untuk menampilkan peta menggunakan pustaka leaflet berserta plugin nya dan peta dari OpenSreetMap, bootstrap sebagai framework css, serta PHP dari sisi backend dan MySQL sebagai basis data. Berdasarkan pengujian automation testing, white box dan kuesioner dapat disimpulkan bahwa sistem ini berjalan dengan baik. Hasil penelitian ini berupa aplikasi WebGIS untuk penyebaran fasilitas umum di Kota Pontianak serta informasi yang berkaitan dari fasilitas umum tersebut, sehingga dapat mempermudah penyampaian informasi lokasi-lokasi fasilitas umum tersebut kepada masyarakat.
\end{abstract}

Kata Kunci: Fasilitas Umum, WebGis, Peta, Leaflet.

\section{Public Facilities WebGis Application Using Leaflet Library and OpenStreetMap}

\begin{abstract}
The existence of public facilities in Pontianak city is spread fairly evenly in various places, but until now not all public facilities are known by the local community or in the future. Therefore, an information system is needed that can present information about the location of public facilities in Pontianak City. The purpose of this research is to build gis web application for the dissemination of public facilities in Pontianak City. The method used in creating this system uses the waterfall method. To display the map using the leaflet library along with its plugin and maps from OpenSreetMap, bootstrap as css framework, as well as PHP from the backend and MySQL as a database. Based on automation testing, white box and questionnaire can be concluded that this system is running well. The result of this research is a WebGIS application for the dissemination of public facilities in Pontianak City as well as related information from these public facilities, so as to facilitate the delivery of information on the locations of public facilities to the public.
\end{abstract}

Keywords: Public Facilities, WebGIS, Maps, Leaflet.

\section{PENDAHULUAN}

Kota Pontianak secara geografis berada tepat dilalui oleh garis khatulistiwa yang berbatasan dengan wilayah Kabupaten Mempawah dan Kabupaten Kubu Raya, yang mana merupakan suatu wilayah yang terus mengalami perkembangan yang pesat dalam berbagai bidang, termasuk bidang kesehatan, pendidikan serta sarana transportasi. Hingga saat ini, terdapat beberapa situs internet yang menyajikan informasi tentang Kota Pontianak misalnya pontianak.go.id, akan tetapi situs tersebut hanya menyajikan informasi fasilitas umum dalam bentuk tabel sehingga informasi yang ditampilkan kurang menarik. Sehingga baik masyarakat luar maupun masyarakat lokal mengalami kesulitan untuk menemukan fasilitas umum seperti rumah sakit, tempat ibadah, tempat pendidikan, kafe hingga tempat wisata.

Demikian juga untuk mencari suatu lokasi fasilitas umum tertentu, masyarakat mulai menggunakan media internet untuk melakukan proses pencarian. Adanya aplikasi-aplikasi SIG dan tools yang bisa dimanfaatkan untuk membuat peta pada halaman website sebagai pengganti peta dinding. Peta dinding segera digantikan dengan tampilan layer-layer peta digital (basis data spasial) dengan simbol-simbol dan warna yang menarik sehingga 
menjadi lebih interaktif yang melibatkan penggunaan peta yang memungkinkan zoom in, zoom out, menjelajah peta, mengidentifikasi fitur-fitur tertentu dan memvisualisasikan informasi tertentu dalam peta yang dapat di implementasikan pada sistem berbasis web. Untuk memenuhi permintaan terhadap informasi lokasi geografis fasilitas di Kota Pontianak, perlu dibangun suatu sistem dalam kesatuan yang utuh dan dapat diakses semua orang

Permasalahan tersebut dibutuhkan suatu aplikasi WebGIS yang mana mampu mengintegrasikan data non spasial dan data spasial yang mempunyai kemampuan baik dalam memvisualisasikan data spasial pada peta. Sehingga diperlukan sistem yang dapat menyajikan informasi lokasi fasilitas umum yang ada di Kota Pontianak serta di bantu dengan pencarian jarak terdekat secara garis lurus dengan haversine formula dan direction service sebagai petunjuk jalan sehingga nanti diharapkan dapat mempermudah pengguna dalam mengakses informasi lokasi fasilitas umum. Berdasarkan uraian diatas maka penulis akan mengangkat judul penelitian yaitu "Aplikasi WebGIS Fasilitas Umum Menggunakan Library Leaflet dan OpenStreetMap".

\section{TINJAUAN PUSTAKA}

\section{A. Sistem Informasi Geografis}

Sistem informasi geografis adalah sistem komputer yang digunakan untuk mengumpulkan, memeriksa, mengintegrasikan, dan menganalisa informasi-informasi yang berhubungan dengan permukaan bumi. Pada dasarnya, istilah sistem informasi geografi merupakan gabungan dari tiga unsur pokok sistem, informasi, dan geografis[1].

Sistem Informasi Geografis (SIG) adalah sistem informasi yang khusus mengelola data yang memiliki informasi spasial (bereferensi keruangan) atau dalam arti yang lebih sempit, adalah sistem komputer yang memiliki kemampuan untuk membangun, menyimpan, mengelola dan menampilkan informasi bereferensi geografis, misalnya data yang diidentifikasi menurut lokasinya, dalam sebuah basis data.

Sistem Informasi Geografis mempunyai kemampuan untuk menghubungkan berbagai data pada suatu titik tertentu di bumi, menggabungkannya, menganalisa dan akhirnya memetakan hasilnya. Data yang diolah pada SIG adalah data spasial yaitu sebuah data yang berorientasi geografis dan merupakan lokasi yang memiliki sistem koordinat tertentu sebagai dasar referensinya. Sehingga aplikasi SIG dapat menjawab pertanyaan seperti lokasi, kondisi, tren, pola dan pemodelan. Kemampuan inilah yang membedakan SIG dengan sistem informasi lainnya.

\section{B. PHP (Php Hypertext Preprocessor)}

PHP adalah bahasa script yang dapat ditanamkan dan disisipkan ke dalam HTML. PHP adalah bahasa pemrograman script server side yang di desain untuk pengembangan web [2].

Dengan demikian kode program yang ditulis dalam PHP tidak akan terlihat oleh pengguna sehingga keamanan web lebih terjamin. PHP dirancang untuk membuat halaman web yang dinamis, yaitu halaman web membentuk suatu tampilan berdasarkan permintaan terkini, seperti menampilkan isi basis data ke halaman web.

\section{Javascript}

Javascript dikembangkan di Netscape dengan nama awal LiveScript yang berfokus pada proses pengolahan data di sisi client dan menyajikan komponen web yang lebih interaktif serta berfungsi untuk menambah fungsionalitas dan kenyamanan halaman web [3]

JavaScript bahasa pemrograman tingkat tinggi dan dinamis. JavaScript populer di internet dan dapat bekerja di sebagian besar penjelajah web populer seperti Google Chrome, Internet Explorer (IE), Mozilla Firefox, Netscape dan Opera. Kode JavaScript dapat disisipkan dalam halaman web menggunakan tag SCRIPT. JavaScript merupakan salah satu teknologi inti World Wide Web selain HTML dan CSS. JavaScript membantu membuat halaman web interaktif dan merupakan bagian aplikasi web yang esensial

\section{Leaflet}

Leaflet adalah perpustakaan JavaScript open-source terkemuka untuk peta interaktif yang ramah mobile. Dengan ukuran hanya sekitar $38 \mathrm{~kb}$, leaflet memiliki semua fitur pemetaan yang paling dibutuhkan pengembang. Leaflet di rancang dengan kesederhanaan, kinerja , dan kegunaan dalam tujuan. Leaflet bekerja secara efisien di semua platform desktop dan seluler utama, dapat diperluas dengan banyak plugin , memiliki Aplication Programming Interface (API) yang indah, mudah digunakan, dan terdokumentasi dengan baik serta kode sumber yang mudah dibaca dan menyenangkan untuk berkontribusi [4].

\section{E. $M y S q l$}

MySQL adalah salah satu aplikasi DBMS yang sudah sangat banyak digunakan para pemrogram aplikasi web. Kelebihan dari MySQL adalah gratis, hebat, selalu diupdate dan banyak forum yang memfasilitasi para pengguna jika memiliki kendala. MySQL juga menjadi DBMS yang sering di bundling dengan web server sehingga proses instalasinya jadi lebih mudah [5].

\section{F. Haversine Formula}

Haversine formula adalah persamaan yang penting pada navigasi, memberikan jarak lingkaran besar antara dua titik pada permukaan bola (Bumi) berdasarkan garis bujur dan garis lintang. Metode ini menghitung jarak antara dua titik dengan berdasarkan panjang garis lurus antara dua titik yang berada pada garis lintang (latitude) dan bujur (longitude) [6]

Hukum haversine adalah semua persamaan yang digunakan berdasarkan bentuk bumi yang bulat (spherical eart) dengan menghilangkan faktor bahwa bumi itu sedikit elips (elispsodial factor). Ini merupakan kasus khusus dari formula umum dalam trigonometri bola, hukum haversine, yang berkaitan dengan sisi dan sudut segitiga bola. Dalam unit bola, sebuah segitiga pada permukaan bola didefinisikan sebagai lingkungan-lingkungan besar yang menghubungkan tiga poin $\mathrm{u}, \mathrm{v}$ dan $\mathrm{w}$ pada bola. Jika panjang dari ketiga sisi adalah a (dari u ke v), b (dari u ke 
w) dan c (dari v ke w), dan sudut-sudut yang berlawanan c adalah C seperti pada Persamaan 2.1.

$\cos (c)=\cos (a) \cos (b) \sin (a) \sin (b) \sin (C)$

Dari persamaan 2.1 diatas kemudian diimplementasikan persamaan haversine seperti persamaan 2.2 berikut.

$$
\text { haversine }(\varnothing)=\sin ^{2}\left(\frac{\emptyset}{2}\right)=\frac{1-\cos (\varnothing)}{2}
$$

Dari formula diatas dapat diimplementasikan rumus untuk menghitung jarak antara titik koordinat sebagai berikut.

$$
d=2 r \cdot \operatorname{arscin}\left\{\begin{array}{l}
\sin ^{2}\left(\frac{\text { lat }_{1}-\text { lat }_{2}}{2}\right) \\
+\cos \left(\text { lat }_{1}\right) \cdot \cos \left(\text { lat }_{2}\right) \\
\left.\cdot \sin ^{2}\left(\frac{\text { long }_{1}-\text { long }_{2}}{2}\right)\right\}
\end{array}\right.
$$

Dimana:

lat ${ }_{1}$, lat $_{2}$ : garis lintang titik 1 dan garis lintang titik 2 (dalam radian)

$\operatorname{long}_{1}, \operatorname{long}_{2}$ : garis bujur dari titik 1 dan bujur dari titik 2 (dalam radian)

$\mathrm{d}=$ Jarak antara dua titik

$\mathrm{r}=$ Radius bumi

\section{G. Software Development Life Cycle}

Software Development Life Cycle (SDLC) adalah proses membuat atau mengubah sistem informasi, model dan metodologi yang digunakan untuk mengembangkan suatu sistem. Dalam rekayasa perangkat lunak, konsep SDLC mendasari berbagai jenis metodologi perangkat lunak. Metodologi - metodologi ini membentuk suatu kerangka kerja untuk perencanaan pembuatan sistem informasi. Model pengembangan SDLC yang di pakai adalah waterfall model yang terdiri dari beberapa tahan seperti analisis kebutuhan, perancangan, implementasi, pengujian dan pemeliharaan [7]

\section{METODOLOGI PENELITIAN}

\section{A. Data Penelitian}

Terdapat dua jenis data yang diperlukan dalam membuat aplikasi webgis fasilitas umum menggunakan library leaflet dan OpenStreetMap antara lain, yaitu:

1. Data primer

Data primer adalah data yang diperoleh dari hasil observasi di lapangan. bantu GPS Map dan data keterangan lokasi. Data lokasi yang terkumpul dalam penelitian ini adalah data sekolah, data bank dan ATM, data rumah sakit dan puskesmas, data pemakaman umum, data tempat ibadah, data perniagaan, data depot air galon, data kafe , data laundry, data PLN dan PDAM, data wifi ID, data SPBU dan kios bensin, data salon dan barbershop, data perpustakaan, data rekreasi dan budaya dan data restoran.

2. Data Sekunder

Data sekunder diperoleh dengan mengumpulkan teori yang berhubungan dengan penelitian ini seperti teori yang didapat dari jurnal, e-book dan website resmi.

\section{B. Metode Pengumpulan Data}

1. Observasi

Observasi dengan cara turun langsung ke lapangan untuk mendapatkan data-data titik lokasi beserta informasi dengan menggunakan alat GPS map untuk mengambil titik koordinat lokasi dan mencatat informasi fasilitas umum dan fasilitas sosial yang diamati di lapangan.

2. Dokumentasi

Data lokasi yang dikumpulkan kemudian di dokumentasikan dalam bentuk gambar yang diambil langsung menggunakan kamera handphone yang diperlukan untuk data pembuatan aplikasi.

3. Studi Literatur

Pengumpulan data dan informasi serta pengetahuan yang didapatkan dari buku-buku, jurnal dan situs di internet mengenai teori yang bersangkutan dalam pembuatan aplikasi.

\section{Metode Pengembangan Sistem}

Pada tahap ini dilakukan desain sistem menggunakan metode perangkat lunak model waterfall. Model waterfall memungkinkan adanya perbaikan sistem pada tahap tertentu harus menyelesaikan seluruh tahap perancangan sistem. Berikut ini merupakan ilustrasi dari metode model waterfall.

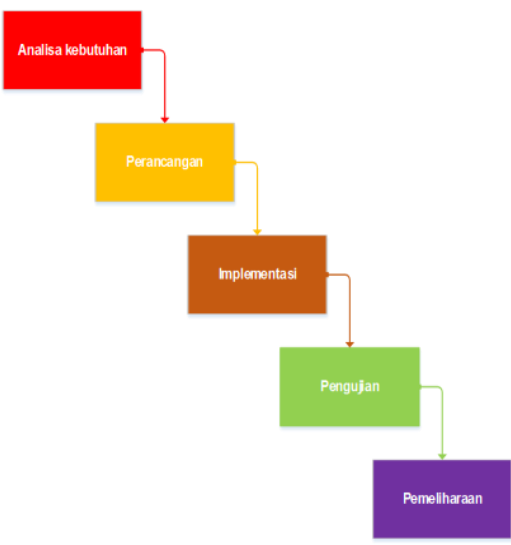

Gambar 1 Model Waterfall 


\section{Arsitektur Sistem}

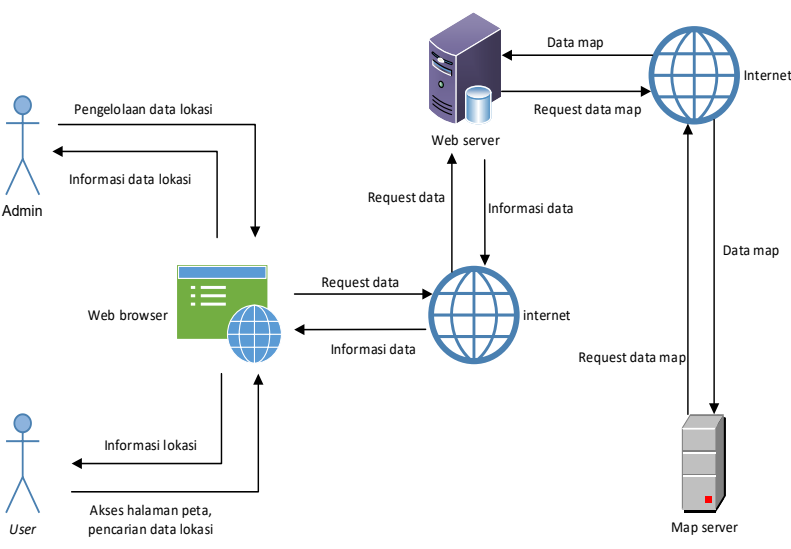

Gambar 2 Arsitektur sistem

Pengguna sistem merupakan admin dan user. User hanya dapat melihat informasi mengenai lokasi , melakukan pencarian lokasi dan mengganti layer peta. Sedangkan admin dapat melakukan pengolahan data. Admin yang sudah login memiliki beberapa akses untuk menambah, mengubah dan menghapus data lokasi dan data master lainnya. Sistem akan melakukan request informasi data kepada web server dan web server yang melakukan request peta pada map server sehingga map server akan memberikan respons dalam bentuk peta digital. User dan admin dapat menerima informasi data ini dalam bentuk peta digital. Pada implementasinya, lokasi fasilitas sosial dan fasilitas umun digambarkan dalam bentuk marker.

\section{E. Diagram Konteks}

Diagram konteks adalah diagram aliran data level tertinggi yang mengilustrasikan sistem informasi sebagai proses bisnis (dengan level nomor 0) yang berinteraksi dengan stake holder (aktor) serta lingkung batasan dari sistemnya.

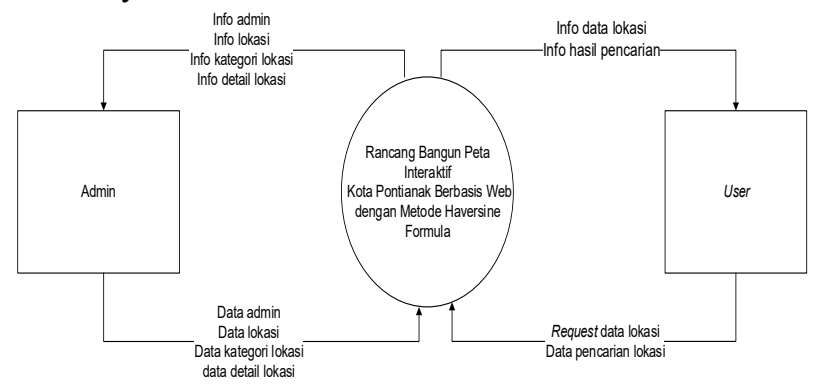

Gambar 3 Diagram konteks sistem

\section{IV.HASIL DAN ANALISIS}

\section{A. Antarmuka Halaman Pengguna}

Sistem yang telah dibangun adalah sebuah website yang responsif dimana tampilannya akan cocok, rapi dan enak dilihat jika di akses perangkat apapun dengan resolusi layar yang berbeda. Misalnya dengan laptop dan smartphone maka tampilan nya akan berbeda. Berikut adalah penjelasan antarmuka sistem yang telah dibangun.

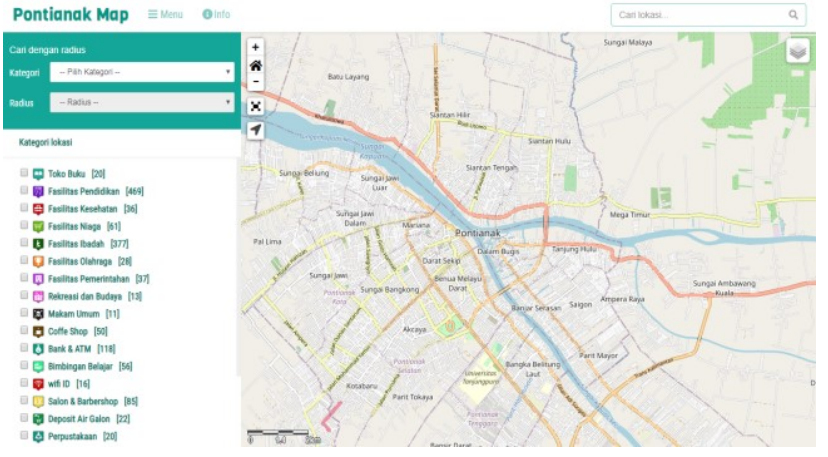

Gambar 4 Antarmuka Halaman Pengguna

\section{B. Antarmuka Pencarian Lokasi}

Pencarian lokasi dengan radius bertujuan untuk mencari lokasi berdasarkan kategori lokasi dan jarak dalam radius yang di pilih oleh pengguna, hasil pencarian akan menampilkan marker lokasi dan daftar tabel berupa nama lokasi.

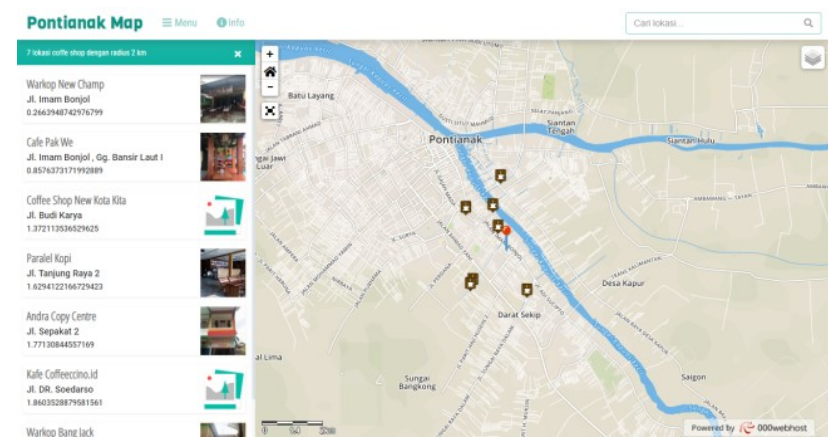

Gambar 5 Antarmuka Pencarian Lokasi

\section{Antarmuka Detail Lokasi}

Tampilan detail lokasi adalah informasi detail dari titik lokasi yang ada pada peta, detail lokasi muncul ketika pengguna mengklik marker pada peta dan daftar nama lokasi pada sidebar.

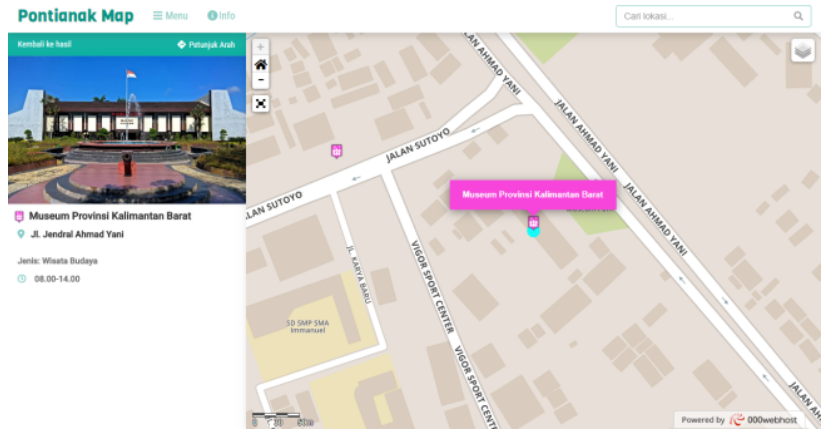

Gambar 6 Antarmuka Detail Lokasi

\section{Antarmuka Petunjuk Arah}

Tombol petunjuk arah tampil ketika pengguna mengklik marker yang menampilkan detail lokasi yang terdapat tombol untuk petunjuk arah. Petunjuk arah dimulai dari posisi pengguna ke lokasi tujuan yang di pilih pengguna. Jarak hasil perhitungan haversine formula juga ditampilkan pada peta. 


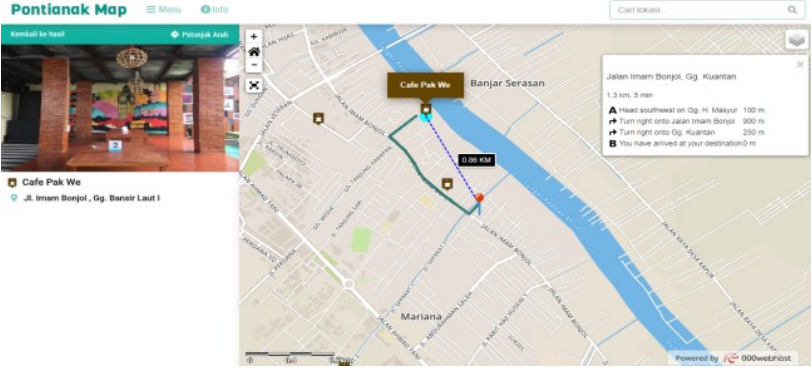

Gambar 7 Antarmuka Petunjuk Arah

\section{E. Hasil Pengujian White Box}

Berikut kode program yang akan dilakukan pengujian white-box dapat dilihat pada tabel 4.4 berikut.

\section{TABEL 1}

KODE PROGRAM IMPLEMENTASI HAVERSINE FORMULA

\begin{tabular}{|c|c|}
\hline Node & Kode program \\
\hline 1 & 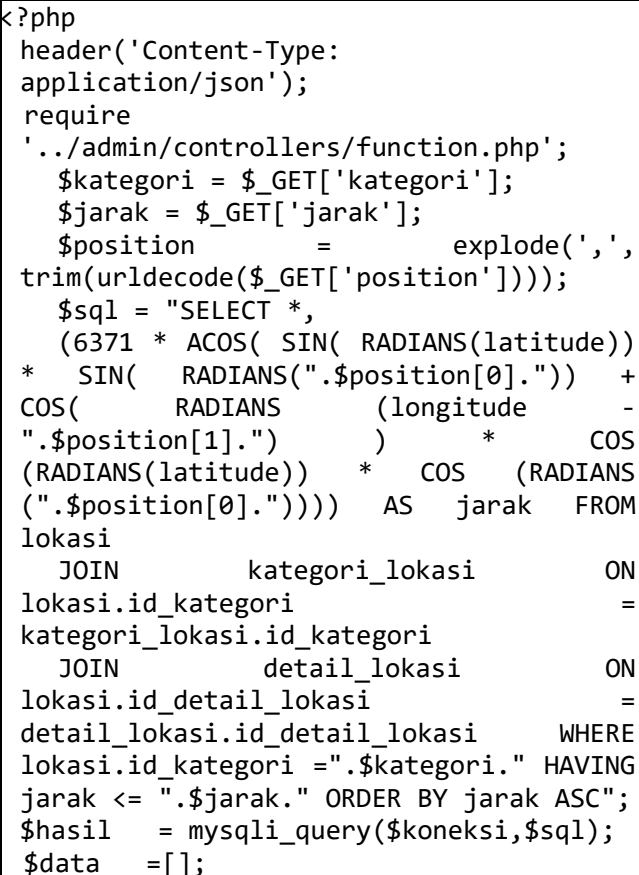 \\
\hline 2 & $\begin{array}{l}\text { while(\$baris } \\
\text { mysqli_fetch_assoc(\$hasil))\{ }\end{array}$ \\
\hline 3 & $\begin{array}{l}\$ \operatorname{data}[]=\text { = baris; } \\
\}\end{array}$ \\
\hline 4 & $\begin{array}{l}\text { echo json_encode } \\
\text { ?> }\end{array}$ \\
\hline
\end{tabular}

Berdasarkan kode program pada tabel 4.3 kode program algoritma haversine formula akan diubah ke dalam bentuk flowgraph yang dapat dilihat pada Gambar 8 berikut.

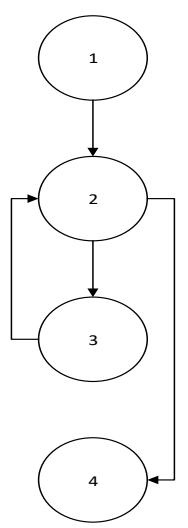

Gambar 8 Flowgraph kode program haversine formula

1) Menghitung cyclometic complexity

Dari Gambar 4.1 dapat dihitung cyclometic complexity, yaitu.

a) $\mathrm{V}(\mathrm{G})=\mathrm{E}-\mathrm{N}+2$

$\mathrm{V}(\mathrm{G})=4-4+2$

$\mathrm{V}(\mathrm{G})=2$

$\mathrm{E}=$ jumlah panah/link pada flowgraph

$\mathrm{N}=$ jumlah simpul pada flowgraph

$\mathrm{V}(\mathrm{G})=$ Cyclometic complexity

b) Menghitung jumlah region

Jumlah region $=$ jumlah kurva tertutup +1 (region terluar)

Jumlah region $=1+1$

Jumlah region $=2$

c) Menghitung jumlah Predicate Node

Predicate node $=1$

$\mathrm{V}(\mathrm{G})=$ jumlah predicate node +1

$\mathrm{V}(\mathrm{G})=1+1$

$\mathrm{V}(\mathrm{G})=2$

2) Menghitung Independent Path

Dari hasil perhitungan cyclometic complexity terdapat 2 independent path yaitu.
1. Path $1=1-2-4$
2. Path $2=1-2-3-2-4$

Untuk melakukan uji coba basis path di atas digunakan graph matrik seperti pada tabel 4.4 berikut.

TABEL 2

GRAPH MATRIKS

\begin{tabular}{|l|l|l|l|l|c|}
\hline Node & 1 & 2 & 3 & 4 & $\begin{array}{c}\text { Jumlah } \\
\mathrm{E}(\mathrm{E})-1\end{array}$ \\
\hline 1 & & 1 & & & $1-1=0$ \\
\hline 2 & & & 1 & 1 & $2-1=1$ \\
\hline 3 & & 1 & & & $1-1=0$ \\
\hline 4 & & & & & 0 \\
\hline \multicolumn{2}{|l}{ Sum(E) +1} & & $\begin{array}{c}+1= \\
2\end{array}$ \\
\hline
\end{tabular}

\section{F. Pengujian Otomasi}

1. Pengujian fungsi cari lokasi dengan radius

Pada halaman ini, form input pencarian dengan radius akan di isi dengan data input berupa kategori lokasi dan radius. Hasil test case yang dilakukan tidak ditemukan langkah yang gagal pada log viewer seperti pada Gambar 9 berikut. 


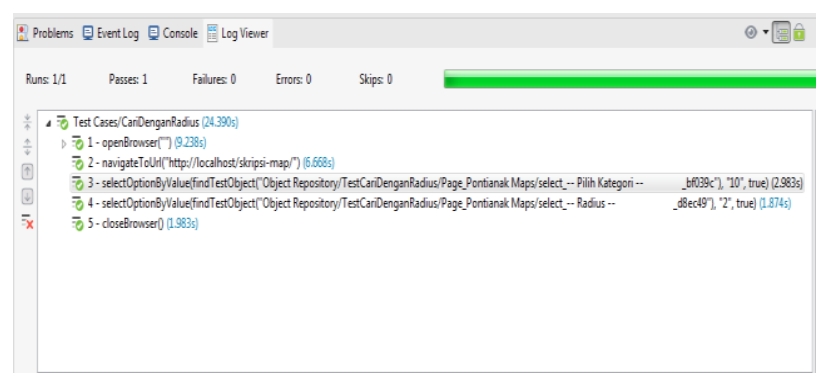

\section{Gambar 9 Test Case Pencarian Lokasi dengan Radius}

2. Test Case Tampilkan Detail Lokasi dan Petunjuk Arah

Pada test case ini proses tampilkan lokasi dimulai dari pengguna memilih lokasi berdasarkan kategori dan radius lalu menampilkan detail lokasi dengan mengklik marker dan meminta petunjuk arah dengan mengklik tombol petunjuk arah. Hasil test case yang dijalankan dapat dilihat pada Gambar 10 berikut.

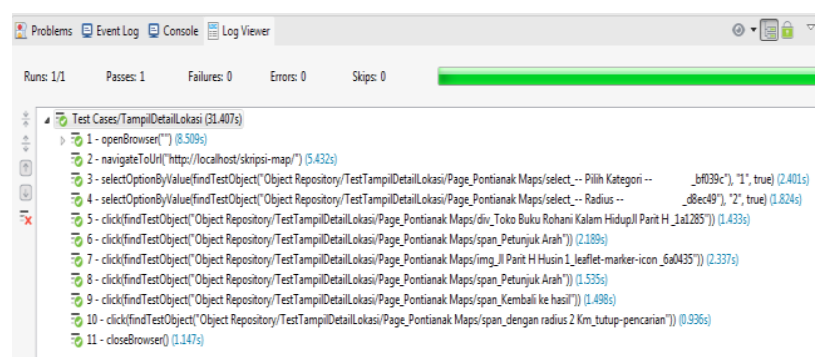

Gambar 10 Test Case Antarmuka Detail Lokasi dan Petunjuk Arah

\section{G. Aspek Fungsionalitas}

Pilihan responden terhadap aspek fungsionalitas sesuai dengan kriteria masing-masing dapat dilihat pada Tabel 4 berikut.

TABEL 4

HASIL KUESIONER ASPEK FungSIONALITAS

\begin{tabular}{|c|l|l|l|l|l|l|l|}
\hline \multirow{2}{*}{ No. } & $\begin{array}{l}\text { Aspek } \\
\text { Fungsionalitas }\end{array}$ & $\mathbf{1}$ & $\mathbf{3}$ & $\mathbf{4}$ & $\mathbf{5}$ & Total \\
\hline 2 & $\begin{array}{l}\text { Apakah web ini } \\
\text { dapat memudahkan } \\
\text { anda dalam mencari } \\
\text { lokasi terdekat? }\end{array}$ & 0 & 0 & 1 & 5 & 10 & 16 \\
\hline $\begin{array}{l}\text { Bagaimana kinerja } \\
\text { web dalam } \\
\text { menampilkan hasil } \\
\text { pencarian lokasi ? }\end{array}$ & 0 & 0 & 1 & 4 & 11 & 16 \\
\hline 3 & $\begin{array}{l}\text { Bagaimana kinerja } \\
\text { web dalam } \\
\text { menampilkan } \\
\text { informasi rute } \\
\text { menuju lokasi yang } \\
\text { diinginkan? }\end{array}$ & 0 & 0 & 0 & 7 & 9 & 16 \\
\hline 4 & $\begin{array}{l}\text { Bagaimana kinerja } \\
\text { web dalam } \\
\text { menampilkan detail } \\
\text { informasi lokasi ? }\end{array}$ & 0 & 0 & 1 & 6 & 9 & 16 \\
\hline
\end{tabular}

\begin{tabular}{|c|l|c|c|c|c|c|c|}
\hline \multirow{2}{*}{ No. } & Aspek & \multicolumn{5}{|c|}{ Tanggapan } & \multirow{2}{*}{ Total } \\
\cline { 2 - 6 } Fungsionalitas & $\mathbf{1}$ & $\mathbf{2}$ & $\mathbf{3}$ & $\mathbf{4}$ & $\mathbf{5}$ & \\
\hline \multirow{2}{*}{5} & $\begin{array}{l}\text { Bagaimana fungsi } \\
\text { fitur web ini secara } \\
\text { keseluruhan? }\end{array}$ & 0 & 0 & 0 & 7 & 9 & 16 \\
\hline \multicolumn{2}{|l|}{ Jumlah } & $\mathbf{0}$ & $\mathbf{0}$ & $\mathbf{3}$ & $\mathbf{2 9}$ & $\mathbf{4 8}$ & $\mathbf{8 0}$ \\
\hline \multicolumn{2}{|l|}{ Persentase (\%) } & $\mathbf{0}$ & $\mathbf{0}$ & $\mathbf{3 . 7 5}$ & $\mathbf{3 6 . 2 5}$ & $\mathbf{6 0}$ & $\mathbf{1 0 0}$ \\
\hline
\end{tabular}

Keterangan : 1 = Sangat Buruk 2 = Buruk $3=$ Cukup Baik 4 = Baik 5 = Sangat Bai

\section{H. Aspek Antarmuka Pengguna}

Pilihan responden terhadap aspek antarmuka pengguna sesuai dengan kriteria masing-masing ditunjukkan pada Tabel 5 berikut.

TABEL 5

Hasil Kuesioner AsPeK ANTARMUKa PENGgunA

\begin{tabular}{|c|l|l|l|l|c|c|c|}
\hline N & Aspek antarmuka & \multicolumn{7}{|c|}{ Tanggapan } & Total \\
\cline { 2 - 7 } o. & pengguna & $\mathbf{1}$ & $\mathbf{2}$ & $\mathbf{3}$ & $\mathbf{4}$ & $\mathbf{5}$ & \\
\hline & $\begin{array}{l}\text { Bagaimana kombinasi } \\
\text { warna, ukuran huruf } \\
\text { dan jenis huruf pada } \\
\text { web ini? }\end{array}$ & 0 & 0 & 1 & 5 & 10 & 16 \\
2 & $\begin{array}{l}\text { Bagaimana tampilan } \\
\text { menu yang ada pada } \\
\text { web ini? }\end{array}$ & 0 & 0 & 0 & 6 & 10 & 16 \\
3 & $\begin{array}{l}\text { Apakah situs web } \\
\text { ditampilkan dengan } \\
\text { baik di browser anda? }\end{array}$ & 0 & 0 & 1 & 4 & 11 & 16 \\
\hline 4 & $\begin{array}{l}\text { Bagaimana tampilan } \\
\text { informasi lokasi dan } \\
\text { petunjuk arah pada } \\
\text { web ini? }\end{array}$ & 0 & 0 & 1 & 6 & 9 & 16 \\
\hline 5 & $\begin{array}{l}\text { Bagaimana tampilan } \\
\text { keseluruhan web ini ? }\end{array}$ & 0 & 0 & 0 & 8 & 8 & 16 \\
\hline Jumlah & $\mathbf{0}$ & $\mathbf{0}$ & $\mathbf{3}$ & $\mathbf{2 9}$ & $\mathbf{4 8}$ & $\mathbf{8 0}$ \\
\hline Persentase (\%) & $\mathbf{0}$ & $\mathbf{0}$ & $\mathbf{3 . 7 5}$ & $\mathbf{3 6 . 2 5}$ & $\mathbf{6 0}$ & $\mathbf{1 0 0}$ \\
\hline
\end{tabular}

Keterangan : $1=$ Sangat Buruk $2=$ Buruk $3=$ Cukup Baik $2=$ Baik $5=$ Sangat Baik

\section{Asek Kegunaan}

Pilihan responden terhadap aspek kegunaan/usability sesuai dengan kriteria masing-masing ditunjukkan pada Tabel 5 berikut.

TABEL 5

HASIL KUESIONER ASPEK KEGUNAAN

\begin{tabular}{|c|l|c|c|c|c|c|c|}
\hline \multirow{2}{*}{ No. } & \multicolumn{2}{|c|}{ Aspek Kegunaan } & \multicolumn{7}{|c|}{ Tanggapan } & Total \\
\cline { 2 - 8 } 1 & $\mathbf{1}$ & $\mathbf{2}$ & $\mathbf{3}$ & $\mathbf{4}$ & $\mathbf{5}$ & \\
\hline & $\begin{array}{l}\text { Bagaimana tingkat } \\
\text { kemudahan pertama } \\
\text { kali menggunakan } \\
\text { web ini? }\end{array}$ & 0 & 0 & 0 & 8 & 8 & 16 \\
\hline 2 & $\begin{array}{l}\text { Bagaimana tingkat } \\
\text { efisiensi ketika } \\
\text { menggunakan web } \\
\text { ini? }\end{array}$ & 0 & 0 & 0 & 6 & 10 & 16 \\
\hline 3 & $\begin{array}{l}\text { Bagaimana tingkat } \\
\text { kemudahan penyajian } \\
\text { informasi pada web } \\
\text { ini? }\end{array}$ & 0 & 0 & 1 & 5 & 10 & 16 \\
\hline 4 & $\begin{array}{l}\text { Bagaimana tingkat } \\
\text { kemudahan dalam } \\
\text { menggunakan fitur- } \\
\text { fitur pada web ini ? }\end{array}$ & 0 & 0 & 0 & 6 & 10 & 16 \\
\hline 5 & $\begin{array}{l}\text { Bagaimana tingkat } \\
\text { kemudahan kontrol } \\
\text { pada web ini? }\end{array}$ & 0 & 0 & 0 & 8 & 8 & 16 \\
\hline
\end{tabular}




\begin{tabular}{|c|c|c|c|c|c|c|c|}
\hline \multirow{2}{*}{ No. } & \multirow{2}{*}{ Aspek Kegunaan } & \multicolumn{5}{|c|}{ Tanggapan } & \multirow{2}{*}{ Total } \\
\hline & & 1 & 2 & 3 & 4 & 5 & \\
\hline \multicolumn{2}{|c|}{ Jumlah } & $\mathbf{0}$ & $\mathbf{0}$ & 1 & 33 & 46 & 80 \\
\hline \multicolumn{2}{|c|}{ Persentase (\%) } & 0 & $\mathbf{0}$ & 1.25 & 41.25 & 57.5 & 100 \\
\hline
\end{tabular}

Keterangan : 1 = Sangat Buruk $2=$ Buruk $3=$ Cukup Baik $4=$ Baik $5=$ Sangat Baik

Berdasarkan hasil kuesioner pada Tabel 3, Tabel 4, Tabel 5 hasil kuesioner dapat disajikan menjadi beberapa bagian, yaitu.

1. Aspek Fungsionalitas

Tanggapan dengan persentase terbesar pada aspek fungsionalitas adalah tanggapan sangat baik (5) dengan nilai persentase sebesar $60 \%$.

2. Aspek Antarmuka Pengguna

Tanggapan dengan persentase terbesar pada aspek antarmuka pengguna adalah tanggapan sangat baik (5) dengan nilai persentase sebesar $60 \%$.

3. Aspek Kegunaan

Tanggapan dengan persentase terbesar pada aspek kegunaan adalah tanggapan sangat baik (5) dengan nilai persentase sebesar $57.5 \%$.

\section{J. User Acceptance Testing}

Berikut adalah perhitungan untuk mengukur tingkat keberhasilan aplikasi dengan menggunakan teknik penskalaan Likert's Summated Rating (LSR) terhadap kuesioner pada Tabel 3, Tabel 4, dan Tabel 5 sebagai berikut.

1. Total tanggapan pada hasil kuesioner (penjumlahan total dari 3 aspek)
1) Total tanggapan $1=0+0+0=0$
2) Total tanggapan $2=0+0+0=0$
3) Total tanggapan $3=3+3+1=7$
4) Total tanggapan $4=29+29+33=91$
5) Total tanggapan $5=48+48+46=142$

2. Total skor tanggapan pada hasil kuesioner

1) Total skor tanggapan $1=0 \times 1=0$

2) Total skor tanggapan $2=0 \times 2=0$

3) Total skor tanggapan $3=7 \times 3=21$

4) Total skor tanggapan $4=91 \times 4=364$

5) Total skor tanggapan $5=142 \times 5=710$

6) Total skor keseluruhan $=0+0+21+364+710=$ 1095

3. Jumlah skor untuk setiap responden

1) Skor maksimal $=5 \times 15$ item $=75$

2) Skor minimal $=1 \times 15$ item $=15$

3) Skor median $=3 \times 15$ item $=45$

4) Skor kuartil $I=2 \times 15$ item $=30$

5) Skor kuartil III $=4 \times 15$ item $=60$

4. Jumlah skor untuk seluruh responden

1) Maksimal $=75 \times 16$ responden $=1200$

2) Minimal $=15 \times 16$ responden $=240$

3) Median $=45 \times 16$ responden $=720$

4) Kuartil I $=30 \times 16$ responden $=480$

5) Kuartil III $=60 \times 16$ responden $=960$

5. Interpretasi jumlah skor tersebut adalah

1) $960<$ Skor $<1200$, artinya sangat positif (program dinilai berhasil).

2) $720<$ Skor $<960$, artinya positif (program dinilai cukup berhasil).
3) $480<$ Skor $<720$, artinya negatif (program dinilai kurang berhasil).

4) $240<$ Skor $<480$, artinya sangat negatif (program dinilai tidak berhasil).

Hasil kuesioner terhadap masyarakat umum dengan nilai total 1095 dapat dikategorikan aplikasi berhasil dengan nilai sangat positif. Hasil penelitian pada interpretasi dapat dilihat pada Gambar 11 berikut.

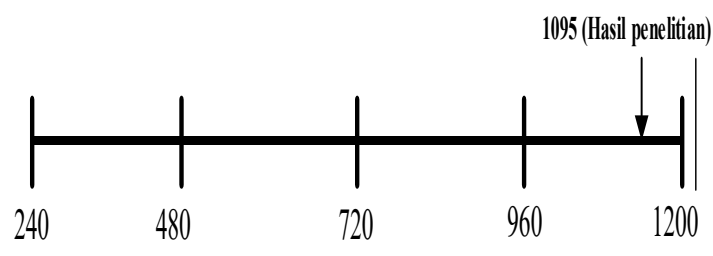

Gambar 11 Hasil Interpretasi LSR

\section{K. Analisis Hasil Kesimpulan}

Berdasarkan hasil uji coba yang telah dilakukan, diketahui bahwa tidak ada selisih perhitungan haversine formula pada aplikasi dan perhitungan dengan microsoft excel jika angka selisih tersebut dibulatkan.

Berdasarkan dari hasil pengujian white box kode program haversine formula didapatkan hasil CC (Cyclomatic Complexity) yaitu 2, independent path 2 dan pada graph matrik bernilai 2 . Hasil pengujian white box menurut hubungan nilai cyclomatic complexity dan risiko termasuk dalam prosedur yang sederhana dengan risiko yang sedang dengan nilai cyclomatic complexity antara 1-4.

Berdasarkan hasil pengujian otomasi dengan aplikasi katalon studio dengan menjalankan test case yang ada, setiap fungsi yang diuji pada sistem tidak ditemukan error pada log viewer katalon studio yang artinya secara fungsional sistem sudah berjalan seperti yang diharapkan.

Berdasarkan hasil kuesioner pada 3 aspek yaitu aspek fungsionalitas, aspek antarmuka pengguna dan aspek kegunaan didapatkan bahwa ketiga aspek tersebut mendapatkan tanggapan tertinggi yaitu sangat baik (tanggapan 5) dari responden, dimana tanggapan tersebut merupakan tanggapan dengan persentase terbesar dari hasil setiap aspek pada kuesioner, dengan persentase tanggapan sangat baik pada fungsionalitas sebesar $60 \%$, aspek antarmuka pengguna sebesar $60 \%$ dan aspek kegunaan sebesar $57.5 \%$. Sedangkan tanggapan terendah yaitu cukup baik (tanggapan 3), dimana tanggapan tersebut merupakan tanggapan dengan persentase terendah dengan tanggapan cukup baik pada aspek fungsionalitas sebesar 3.75\%, aspek antarmuka pengguna sebesar $3.75 \%$, aspek kegunaan sebesar $1.25 \%$.

Berdasarkan hasil User Acceptance Test, dapat diketahui bahwa responden menilai bahwa aplikasi yang dibuat sangat positif dan berhasil, yang dapat dibuktikan dengan skor total dari keseluruhan data kuesioner berjumlah 1095, dimana total skor ini berada diantara kuartil III (960) dan maksimal (1200) pada interpretasi LSR.

\section{KESIMPULAN}

Hasil penelitian yang dilakukan menunjukkan bahwa aplikasi yang dibangun mampu menyajikan data fasilitas umum dengan fitur pencarian lokasi dan petunjuk arah 
menuju lokasi tujuan serta mampu menghasilkan fitur perhitungan berdasarkan garis lurus dan ditampilkan antara titik asal dan titik tujuan yang ditampilkan dalam bentuk polyline sebagai kisi-kisi jarak terdekat.

Berdasarkan analisis dan pengujian yang dilakukan, maka kesimpulan yang dapat diambil adalah.

\section{DAFTAR PUSTAKA}

[1] K. M. Wibowo, K. Indra, and J. Jumadi, "Sistem Informasi Geografis (SIG) Menentukan Lokasi Pertambangan Batu Bara di Provinsi Bengkulu Berbasis Website," J. Media Infotama, vol. 11, no. 1, pp. 51-60, 2015, [Online]. Available: https://jurnal.unived.ac.id/index.php/jmi/article/view/252/231.

[2] M. Madiun Andi, Sukses membangun toko online dengan PHP dan mySQL. Yogyakarta, 2016.

[3] A. Solichin, Pemrograman Web dengan PHP dan MySQL. Jakarta, 2016.

[4] "Leaflet." https://leafletjs.com (accessed Feb. 06, 2020).

[5] P. Hidayatullah and J. K. Kawistara, "Pemrograman Web Edisi Revisi," Informatika, 2018.

[6] Glen Van Brummelen, Heavenly Mathematics: The Forgotten Art of Spherical Trigonometry. Princeton University Press, 2013.

[7] U. Proboyekti, "Bahan Ajar Rekayasa Perangkat Lunak Agile Software Development," Univ. Kristen Duta Wacana, 2008. 